\title{
On the Application of Multicultural Education in Chinese Higher Education
}

\author{
Xu Xiaoshi \\ Jilin Agricultural University, Changchun ,China \\ E-mail: xiaoshitou2001xxs@163.com
}

Keywords: Multiculture; Multicultural Education; higher education

\begin{abstract}
Multicultural education is a hot issue in today's education circle, which is an important measure to build a new multicultural education under the new situation and promote social harmony. The idea of multicultural education is recognized and accepted by Chinese educators. The paper, based on the Western multicultural education concepts and measures, combined with China's actual situation, analyzes the positive effect of multicultural education in the process of development of higher education in China.
\end{abstract}

\section{Introduction}

The current economic globalization will inevitably bring about cultural diversity. As cultural exchanges become more frequent, the conflict and blending of different cultures not only bring a big challenge for our modern education, but also provide opportunities for higher education development. As a multi-ethnic country, China shall, first of all based on their own national study of multicultural education, look for multicultural education mode suited to its national conditions. The multicultural education of higher education in China is slightly left behind. In this context, the university should strengthen the study of multicultural education to adapt to different cultural backgrounds of learning needs of students, and create equal opportunities for learning and development.

\section{Concept of Multicultural Education}

At present, the concept of multicultural education in the academic community has not reached a consensus. Due to the fact that the multicultural education originated in the West, the definition of multicultural education mainly adopts some of the Western countries' evaluation standards and systems, At present, some characteristics of multicultural education coincide with Chinese multicultural education, that is, many western multicultural education category and environment are in line with the actual development of multicultural education in China.

First of all, the category of multicultural education should be clarified. Western scholars believe that multicultural education is a multi-ethnic education, a concept of improving the education for different nationalities only. Extensiveness of multicultural education should include: enhancing equal opportunities in education, promotion of multiculturalism, changing lifestyles, respect for differences and promoting the balance of power. 
Next point is, multicultural education is regarded as the helping education and the education of helping disadvantaged groups by some Western scholars. I feel this is not comprehensive. The range of Multicultural education concludes all the students receiving education mentioned above. Multicultural education should be designed to educate students how to care for others better, how to care for the community, and how to become a responsible citizen in a pluralistic society.

In conclusion, the author of the paper thinks the concept of multicultural education, in a more rational analysis, could be defined as what Banks did: "Firstly, as to multicultural education, it is an an educational concept which advocates all students should be given equal opportunities of learning regardless of genders, social classes, ethnics, races, religions and cultural characteristics; Secondly, multicultural education is a movement of educational reform, which attempts to reform the structure of the education system. Whereas the above students may enjoy the equal opportunities of getting academic accomplishments. Last but not the least, multicultural education is a developing process in constant, which could not resolve the particular issues, but also it is a innovating process to reform the social system and education system totally. However, this process is in a long way."

The exploration and discussion of the concept of multicultural education contributes to a scientific understanding of multicultural education in China's reform and opening and to the access to the international community, which will make our educational notions and methods learn from the advanced countries in order to enrich educational deficiencies in the development process.

\section{Background of Multicultural Education}

In history, the establishment and improvement of multicultural education system is due to the increase of immigrants in Western countries, leading to the formation of multi-ethnic society. In order to provide a fair and mutually friendly environment for higher education, the Western countries started to implement multicultural education so that different ethnic groups can receive higher education, so as to reduce the friction between nations.

From a sociological perspective, multicultural education has profound social factors, mainly attributed to moderate assimilation theory, radical assimilation theory, mild multiculturalism, radical multiculturalism in four. Mild multiculturalism is relatively scientific patterns of social culture structure. There must be the important base in society for China's multicultural education in college, that is the gentle structure of multicultural society.

China's multicultural education includes the internal flow and multilateral learning among the ethnic groups, which enhence the contact of the necessity. As a result, the multicultural education in the promotion and implementation of colleges is the inevitable purpose to make Chinese culture better, more open to the direction of the development.

\section{Measures of Multicultural Education}

From the reality of the development of higher education in China, the multicultural education in China has just started; the multicultural education system has not been established and perfected in China. Multicultural education is the objective requirement of the progress of Chinese society, and the essential education policies to participate in the world competition, coordinate social contradiction, and maintain the unification of the motherland under globalization. 
First of all, multicultural education in China should be based on the unified society, with both unity of multicultural education background and the unique value of national culture independent existence. Respecting for differences between different cultures and coordinating between different cultural tendency of college students, colleges and universities try to meet the students' understanding of different cultures and understanding. Multicultural education in universities is the patriotism education to build a unified social education, the social education to maintain social stability, and the moral education to respect for others and different cultures. In the education constructing process of unified patriotism multiculture, universities emphasize on the unity of different races, genders, ages and social classes. And the universities open the courses of general focuses. The students, Under different cultural backgrounds, get together to accept the courses in common hobbies, can forms solidarity directly, at the same time promote the unified identity of cultures. China established the universities in terms of different races. The students of different races, could learn different cultures, deepen the understanding of multified cultures. Meanwhile, the international exchanges and cooperation among different universities, will promote different area college students understanding different geography and culture, especially between the universities of minority races and Comprehensive University, which is the essence of strengthening the multicultural education.

In the second place, the state should focus on the and implementation of multicultural education which has been conducted much earlier in the occidental countries. With the precedent experiences, China will take the worthy experience to promote the educational reform For instance, in recent years, France put forward the concept of "different rights" on multicultural education to protect the minorities for respecting their cultural uniqueness. In the process of promoting multicultural education, China should ensure that all the equal rights of get higher education by respecting racial traditions in culture.

Finally, multicultural education is a constantly substantial topic and also a with regional characteristics. To ensure the transmission of the concept of multicultural education in China properly, to show the racial cultures fairly, the universities shall strengthen cultures exchanges and integration to form a multicultural education system, which is suitable for the interests of all races. Multicultural education is a systematic project involving not only education fields but also sociology, ethnology, co-ordination, law, etc. The in this field needs all the scholars to continue to deepen its understanding and on emerging problems. So I believe that China's multicultural education is bound to make contributions to national unity and social stability.

\section{Summary}

This paper starts with the concept of multicultural education, concentrates on the actual situation of higher education in China and believes that multicultural education reform in China should be based on the opening up to connect with the international community. On the Concept of education our country should draw lessons and learn from advanced countries, keep an objective attitude to analyze the background of the world of multicultural education, know that it's important to implement multicultural education in higher education, and put forward something as follows on the premise that builds a harmonious society and safeguard national unity:

1. China's multicultural education shall be harmonized in a unified society, awhich contains the context of multicultural education uniform as well as the unique values. 
2.China shall intend to the study and experiment of implementinig multicultural education, and the Western countries start much earlier in this aspect, so they have plenty of valuable experience which is worthy of promoting the educational reform process to learn and for China.

3. It is a a theme of substantial subject of multicultural education, and still with multified characteristics in different regions.

\section{References}

[1]Qian, M.H. On the Concept of Multicultural Education and Practice. Journal of Peking University/ Philosophy and Social Sciences , (2011), p.136-143

[2]Shao, X.X. Seeing Our Multicultural Education from the National Unity Education Courses. Journal of Yunnan University of Nationalities Academic /Philosophy and Social Sciences, (2011), p.19-24

[3]Han, H. The Theory and Practice View of American Multicultural Education in 90s. Comparative Education Review, (2000), p.46-50

[4]Su,D. Content and Curriculum Construction of Minority Multicultural Education.Journal of Central University of Nationalities /Philosophy and Social Sciences, (2008), p.88-94

[5]Wan, M.G. Dilemma and Development of Multicultural Education. Journal of Northwest Normal University(Social Sciences), (2007), p.58-62

[6]Peng, Y.C.U.S. University Study of the Evolution of Multicultural Education. East China Normal University, Doctoral Thesis, (2004), p.13-14

[7]Hu,S. The International Encyclopedia of Education,NY:Pergamon press, (1985) p.1267 